\title{
PREVALENCE OF SUBCLINICAL MASTITIS IN A DAIRY HERD IN BENI-SUEF GOVERNORATE
}

\author{
A.M.S. Meshref and M.H.A. Tolba \\ Food hygiene and control department \\ Fac. of Vet. Med., Beni-Suef University
}

\begin{abstract}
A total of 115 dairy cows were screened by California mastitis test (CMT) to estimate the prevalence of subclinical mastitis in a dairy herd in Beni-Suef Governorate, as well as Somatic cell count ( SCC) of 28 bulk tank milk samples were estimated using De-Laval cell counter. Mean bulk tank SCC (BTSCC) was $9.5 \times 10^{5} \pm 7.5 \times 10^{4}$ with the highest frequency of distribution (64.3\%) lies within the range of $5 \times 10^{5}$ to $1 \times 10^{6}$. The prevalence of subclinical mastitis was $15.2 \%$ on an udder quarter basis and $39.1 \%$ on a cow basis. The organisms that were most frequently isolated were E.coli (35.4\%), Str.bovis (21.5\%), Str.agalactiae (10.8\%), Coagulase negative Staphylococci (CNS) (7.7\%), S.aureus (6.2\%), Str.dysgalactiae (3.1\%) and Str.faecalis $(3.1 \%)$ for single infection while for double infection were Str.bovis with S.aureus (6.2\%), Str.bovis with E.coli (3.1\%), Str.agalactiae with S.aureus (1.5\%) and Str.bovis with CNS (1.4\%). In conclusion subclinical mastitis is a serious problem in dairy industry and its early detection is the corner stone in its control.
\end{abstract}

\section{INTRODUCTION}

Mastitis is a major cause of economic loss in the dairy industry worldwide. It occurs in both clinical and subclinical forms. Subclinical form is believed to be more prevalent than clinical form in most countries (Schukken et al., 1995). The prevalence of subclinical mastitis on farms could range from 19 to $78 \%$ (Tuteja et al., 1993). Of great 
economic significance is the fact that subclinical mastitis may cause between 15 and $45 \%$ reduction in milk production in affected lactating cows (Dohoo and Meek, 1982).

Somatic cell count (SCC) has been accepted as the best index to use to both evaluate milk quality and predict udder infection in cow (Pyorala, 2003). Under field conditions determination of SCC in cows milk is usually performed by California mastitis test (CMT).

Certain species of bacteria notably S. aureus, Str. agalactiae, Str. dysgalactiae, Str. uberis, E .coli and C.bovis are most commonly implicated in mastitis .Str. agalactiae and S. aureus are most commonly implicated in mastitis and are spread between udder quarters and cows primarily during milking, since the major source of the organisms within the herd is the infected udder.Other organism like E. coli, Str. uberis, Str. dysgalactiae and C.bovis are less dependent on the milking process for their dissemination within the herd, as they are mainly found on cow and in the environment and related to poor hygienic measure (Bramley and McKinnon, 1990).

Therefore, the purpose of our study was : 1) To provide information in udder health. 2) To estimate the prevalence of subclinical mastitis in a dairy farm in Beni-Suef Governorate and 3) To investigate the aetiological agent of subclinical mastitis.

\section{MATERIALS AND METHODS}

\section{1- Bulk tank milk examination:}

28 bulk tank milk samples (each 2 days) were collected regularly from storage tank (after thorough mixing ) of a dairy herd in Beni-Suef governorate for determination of bulk tank somatic cell count (BTSCC) using De-Laval cell counter according to the manufacture's instructions. 


\section{2- Individual cow examination:}

\section{A- California mastitis test (CMT):}

A total of 460 quarters from 115 dairy cows in a dairy herd in BeniSuef governorate were investigated for sub-clinical mastitis using CMT. The results were read and evaluated according to $\boldsymbol{A P H A}$, (1993). Scores represented 4 categories; 0 , negative or trace; $1+$, weak positive; $2+$ distinct positive and $3+$, strong positive.

\section{B- Bacteriological examination:}

70 milk samples were collected aseptically from quarters diagnosed with $\mathrm{CMT} \geq 1+$. Loopfuls of the milk sediment (after centrifugation at $3000 \mathrm{rpm}$ for 20 minutes) were streaked onto sheep blood agar, Mac Conkeys agar and Edwards agar media and incubated aerobically at 37 ${ }^{\circ} \mathrm{C}$ for 48 hours. Suspected colonies were isolated in a pure culture and identified according to Bailey and Scott (1994).

\section{RESULTS AND DISCUSSIONS}

Table (1): Statistical analytical result of BTSCC (/ml milk).

\begin{tabular}{||c||c||c||c||}
\hline Minimum & Maximum & Mean & SEM \\
\hline \hline $5 \times 10^{5}$ & $1.7 \times 10^{6}$ & $9.5 \times 10^{5}$ & $7.5 \times 10^{4}$ \\
\hline
\end{tabular}

Table (2): frequency distribution of BTSCC.

\begin{tabular}{|c|c||c|c||c|c||}
\hline \multicolumn{2}{||c||}{$<5 \times 10^{5}$} & \multicolumn{2}{|c||}{$5 \times 10^{5}-1 \times 10^{6}$} & \multicolumn{2}{c|}{$>1 \times 10^{6}$} \\
\hline No & $\%$ & No & $\%$ & No & $\%$ \\
\hline \hline 0 & 0 & 18 & 64.3 & 10 & 35.7 \\
\hline
\end{tabular}


Prevalence Of Subclinical Mastitis In A Dairy ...

Table (3): Prevalence of subclinical mastitis in examined dairy herd defined by positive CMT

\begin{tabular}{||c||c|c||c|c||c|c||}
\hline \multirow{2}{*}{$\begin{array}{c}\text { No of } \\
\text { examined } \\
\text { quarters }\end{array}$} & \multicolumn{2}{c||}{$\begin{array}{c}\text { No. of } \\
\text { positive } \\
\text { quarters }\end{array}$} & \multicolumn{2}{c||}{$\begin{array}{c}\text { No. of } \\
\text { positive dairy }\end{array}$} & \multicolumn{2}{c||}{$\begin{array}{c}\text { No. of } \\
\text { negative dairy } \\
\text { cows }\end{array}$} \\
\hline \multirow{2}{*}{460} & No. & $\%$ & No. & $\%$ & No. & $\%$ \\
\cline { 2 - 7 } & 70 & 15.2 & 45 & 39.1 & 70 & 60.9 \\
\hline
\end{tabular}

Table (4): incidence of bacteria isolated from CMT positive quarter milk samples.

\begin{tabular}{|c|c|c|c|c|c|c|c|}
\hline \multicolumn{2}{|c|}{$\begin{array}{l}\text { positive } \\
\text { quarters }\end{array}$} & \multicolumn{3}{|c|}{ Single infection } & \multicolumn{3}{|c|}{ Double infection } \\
\hline No & $\%$ & Organism & No & $\%$ & Organism & No & $\%$ \\
\hline \multirow{7}{*}{65} & \multirow{7}{*}{92.9} & Str. agalactiae & 7 & 10.8 & Str. agalactiae + S. aureus & 1 & 1.5 \\
\hline & & Str. dysgalactiae & 2 & 3.1 & Str. bovis + S. aureus & 4 & 6.2 \\
\hline & & Str. bovis & 14 & 21.5 & Str. bovis + CNS & 1 & 1.4 \\
\hline & & Str. faecalis & 2 & 3.1 & Str. bovis + E.coli & 2 & 3.1 \\
\hline & & S. aureus & 4 & 6.2 & & & \\
\hline & & CNS* & 5 & 7.7 & & & \\
\hline & & E.coli & 23 & 35.4 & & & \\
\hline \multicolumn{2}{|c|}{ Total } & & 57 & 87.8 & & 8 & 12.2 \\
\hline
\end{tabular}

*CNS: Coagulase negative Staphylococci.

The data summarized in Table $(1 \& 2)$ revealed that the bulk tank milk samples contained SCC from $5 \times 10^{5}$ to $1.7 \times 10^{6}$ with a mean count of $9.5 \times 10^{5} \pm 7.5 \times 10^{4}$ cells $/ \mathrm{ml}$. The highest frequency of distribution $64.3 \%$ lies within the range of $5 \times 10^{5}$ to $1 \times 10^{6}$ cells $/ \mathrm{ml}$ milk.

Kafrelsheikh Vet. Med. J. Vol. 5 No. 1 (2007) 
In comparison similar finding was reported by Kinabo and Assey (1993) they found the mean SCC of university farm in Tanzania was $9 \mathrm{x}$ $10^{5}$ cells $/ \mathrm{ml}$. on the other hand lower values were reported by Barkema etal., (1998), Buato etal., (2000), Jayarao etal., (2004), Meshref, (2004), Van Schaik etal., (2005), Hamilton etal., (2006), and Richard et al., (2006). While higher higher values were reported by Weidmann et al., (1986) and Sobeih, (2000) during winter season.

It well established that BTSCC are a good indicator of general state of udder health and the condition under which milk is produced in the dairy herds. Herds with BTSCC $<2.5 \times 10^{5}$ cells $/ \mathrm{ml}$ are approaching the optimal level of udder health (Peeler et al., 2002), while herds with BTSCC > $5 \times 10^{5}$ cells $/ \mathrm{ml}$ have important problems with subclinical mastitis (Dohoo and Meek, 1982). Elevated SCC are associated with decrease in milk production, rise in whey protein plus a decrease in casein resulting in considerably decreased cheese yields and shorter shelf life and adverse milk flavour (Harding, 1995).

The prevalence of subclinical mastitis $(\mathrm{CMT}>0)$ at the quarter level was $15.2 \%$, while at the cow level (at least one positive quarter per cow) was $39.1 \%$ (Table. 3 ).

The obtained prevalence of subclinical mastitis was nearly similar to that recorded by Kassa et al., (1999), Mulei, (1999) and Roesch et al., (2007), while was higher than those reported by Wilson and Richards, (1980) and Hamilton et al., (2006) and lower than those reported by Todorov et al., (1981); Busato et al., (2000); Ahmed and Deeb-Azza (2001); Gianneechini et al., (2002); Mdegela et al., (2004); Abdel-Khalek and El-Sherbini (2005); Haltia et al., (2006); Karimuribo et al., (2006) and Kivaria et al., (2007). 
Regarding the main etiological agent of subclinical mastitis, it is clearly observed that the most frequently isolated pathogens were E.coli (35.4\%), Str.bovis (21.5\%), Str.agalactiae (10.8\%), CNS (7.7\%), S.aureus (6.2\%), Str.dysgalactiae (3.1\%) and Str.faecalis (3.1\%) as a single infection while as a double infection were Str.bovis with S.aureus (6.2\%), Str.bovis with E.coli (3.1\%), Str.agalactiae with S.aureus (1.5\%) and Str.bovis with CNS (1.4\%) (Table, 4).

Similar causative organisms in a different percentages were reported by Gonzalez et al., (1988); El-Kholy et al., (1994); Busato et al., (2000); Ahmed and Deeb-Azza (2001); Gianneechini et al., (2002);Anwer et al., (2003); Janosi and Baltay, (2004); Mdegela et al., (2004); Shitandi and Kihumbu (2004);Green et al., (2005); Karimuribo et al., (2006) and Bradley et al., (2007).

S.aureus and Str.agalactiae are serious problem that affects many dairy cows resulting in a significant loss of milk production. They are extremely contagious and found primarily in the infected quarters. Infections with these organisms are transmitted from quarter to quarter and from cow to cow primarily at milking time through milking units. It is also spread by not disinfecting teats, milkers hand and by lack or improper post-milking teat dipping.

Among the organisms causing mastitis, Str.agalactiae, S.aureus and E.coli, are pathogenic for man. Str.agalactiae is responsible for a variety of clinical conditions, of which the most serious is an often fatal bacteraemia and meningitis of the newborn. Some bovine strains of S.aureus produce enterotoxins during milk storage (heat stable) which cause nausea, diarrhea and abdominal pain, moreover high number of E.coli may be present in milk as a consequence of mastitis, and this species is responsible for several different diseases of man of varying severity (Bramley and McKinnon, 1990). 
The presence of subclinical mastitis results in decreased milk production, a greater incidence of clinical mastitis, higher treatments costs, increased culling rate as well as reduced the suitability of raw milk for manufacture and processing into products for human consumption in addition to risk of milk contamination with pathogens and antibiotics residues.

In conclusion subclinical mastitis is a serious problem in dairy industry and its early detection is the corner stone in its control. In addition to dry cow therapy, post-milking teat dipping, application of strict hygienic measures during milking, maintenance of clean and dry environment, special attention to equipment sanitation and milkers hygiene and culling of persistent offenders from the herd is also important in control of mastitis.

\section{REFERENCE}

- Abdel-Khalek, A. and El-Sherbini, M. (2005): Prevalence of contagious pathogens of bovine subclinical mastitis and relationship to bacteria and somatic cell count. $4^{\text {th }}$ Int. Sci. Conf., Mansoura, 5-6 April, 2005.

- Ahmed H.F. and Deeb-Azza M.M., (2001): Prevalence of subclinical mastitis in dairy cows in Kafr El-Sheikh and ElGharbia Governorates with special observation to antibiotic sensitivity. $6^{\text {th }}$ Sci. Cong. Egyptian Society for cattle Diseases, 4-6 Nov. 2001, Assiut, Egypt.

- Anwer, W., Badawi Mohga, F., and Moustafa Gehan Z., (2003): Environmental microorganisms causing mastitis in dairy cattle reared under different hygienic measures. J. Egypt.Vet.Med.Assoc., 63:1,161-170.

- APHA (1993): Standard methods for the examination of dairy 
products. $16^{\text {th }}$ ed., American public Health Association, Washington.

- Bailey, W.R. and Scott, E.C., (1994): Diagnostic microbiology. $9^{\text {th }}$ Ellen J. Baron, Lancer R. Peterson and Sydney M. Finegold. The C.V. Mosby Co., Saint Louis.

- Bradley, A.J., Leach, K.A., Breen, J.E., Green, L.E. and Green, M.J., (2007): Survey of the incidence and aetiology of mastitis on dairy farms in England and Wales. Vet.Rec., 160:8, 253-257.

- Bramley, A.J. and McKinnon, C.H., (1990): The microbiology of raw milk. P. 163-208. In dairy microbiology, Vol.1, Robinson, R.K., (ed.), Elsevier applied science, London and New York.

- Busato A., Trachsel P., Schallibaum M. and Blum J.W., (2000): Udder health and risk factors for subclinical mastitis in organic dairy farms in Switzerland. Prev.Vet.Med. 44, 205-220.

- Dohoo, I.R., and. Meek, A.H, (1982): Somatic cell counts in bovine milk. Can. Vet.J.23, 119-125.

- El-Kholy, A.M.,Hosein, H.I. and Thabet, A.El-R., (1994): Chemical and cytobacteriological studies for detection of subclinical mastitis. Assiut Vet. Med. J., 30:60,154-164.

- Gianneechini, R., Convha, C., Rivero, R., Delucci, I., and Moreno Lopez, J., (2002): Occurrence of clinical and subclinical mastitis in dairy herds in the west littoral region in Uruguay. Act Vet. Scand., 43:4,221-230.

- Gonzalez, R.N., Jasper, D.E., Farver, T.B., Bushnell, R.B., and Franti, C.E., (1988): Prevalence of udder infections and mastitis in 50 California dairy herds. J. Am. Vet.Med. Assoc., 
1:93,323-328.

- Green, M.J., Green, L.E., Bradley, A.J., Burton, P.R., Schukken, Y.H., and Medley, G.F., (2005): Prevalence and association between bacterial isolates from dry mammary glands of dairy cows. Vet. Rec., 156:3, 71-77.

- Haltia, L., honkanen-Buzalski, T., Spiridonova, I., Olkonen, A., and Myllys, V., (2006): A study of bovine mastitis , milking procedures and management practices on 25 Estonian dairy herds. Acta Vet Scand.,48:1,22.

- Hamilton C., Emanuelson U., Forslund K., Hansson I. and Ekman T., (2006): Mastitis and related management factors in certified organic dairy herds in Sweden. Acta Vet. Scand. 48:1,11.

- Harding F.,(1995): Milk quality. Blackie Academic and Professional.

- Jansoi, S., and Baltay, Z., (2004): Correlations among the somatic cell count of individual bulk milk, result of California mastitis test and bacteriological status of udder in dairy cows. Acta Vet Hung., 52:2. 173-183.

- Jayarao B.M., Pillai S.R., Sawant, A.A., Wolfgang and Hegde N.V., (2004): Guidelines for monitoring bulk tank somatic and bacterial counts. J. Dairy Sci. 87: 3561-3573.

- Karimuribo, E.D., Fitzpatrrick, J.L., Bell, C.E., Sawai, E.S., Kambarage, D.M., Ogden, N.H., Bryant, M.J., and French, N.P., (2006): Clinical and subclinical mastitis in smallholder dairy farms in Tanzania: Risk, intervention and knowledge 
transfer. Pre. Vet. Med., 74:1, 84-98.

- Kassa T., Wirtu G., and Tegegne A., (1999): Survey of mastitis in dairy herds in Ethiopian central highlands. Etiopiah J. Sci., 22:291-301.

- Kinabo, L.D.B., and Assey, R.J., (1993): Bovine mastitis in selected dairy farms in Morogoro district, Tanzania. Beitrage Zur Tropischen Landwirtschaft und Veterinarmedizin, 21:1, 65-71.

- Kivaria, F.M., Noordhuizen, J.P.T.M., and Nielen, M., (2007): Interpretation of California mastitis test scores using Staphylococcus aureus culture results for screening of subclinical mastitis in low yielding smallholder dairy cows in the Dar es Salaam region of Tanzania. Prev. Vet. Med., 78:274285.

- Mdegela, R.H., Kusiluka, L.J.M., Kapaga, A.M., Karimuribo, E.D., Turuka, F.M., Bundala, A., Kivaria, F., Kabula, B., Manjurano, A., Loken,T.and Kambarage,D.M., (2004): Prevalence and determinants of mastitis and milk borne zoonoses in smallholder dairy farming sector in Kibaha and Morogoro districts in eastern Tanzania. J. vet. Med. B51, 123128.

- Meshref A.M.S., (2004): Risk factors affecting the bacteriological quality of farm bulk milk. Ph.D. thesis, Fac. of Vet. Med., Cairo University.

- Mulei, C.M., (1999): Teat lesions and their relationship to intramammary infections on small - scale dairy farms in 
Kiambu district in Kenya. J.S. Afr.Vet. Assoc.,70:156-157.

- Peeler E.J., Green, M.J., Fitzpatrick, J.L., and Green, L.E., (2002): A study of clinical mastitis in British dairy herds with bulk milk somatic cell counts less than 150000 cells/ml. Vet. Rec., 151:170-176.

- Pyorala, S., (2003): Indicators of inflammation in the diagnosis of mastitis. Vet. Res. 34,565-578

- Richard G.M., Riekerink O., Barkema H.W., Veenstra V., Poole D.E., Dingwell R.T., Keefe G.P., (2006): Prevalence of contagious mastitis pathogens in bulk tank milk in Prince Edward Island. Can. Vet. J. 47:6, 567-572.

- Roesch M., Doherr G.M., Scharen W., Schallibaum M. and Blum J.W., (2007): Subclinical mastitis in dairy cows in Swiss organic and conventional production systems. J. Dairy Res., $74: 1,86-92$.

- Schukken, Y.H., Lam, T.J. , Nielen, M., Hogeveen, H. Barkema, H. W., and Grommers, F.J., (1995): Subclinical mastitis on dairy farms in the Netherlands: epidemiological development. TijdschriftV. diergen. 120, 208 - 213.

- Shitandi, A. and Kihumbu, G., (2004): Assessment of the California mastitis test usage in small holder dairy herds and risk of violative antimicrobial residues. J.Vet.Sci.,5:1, 5-9.

- Sobeih-Azza M.K.H., (2000): Studies on raw milk quality in Kafr El-Sheikh.Ph.D. thesis, Tanta University, Kafr El-Sheikh branch.

- Todorov D., Ikonomov L., Slavchev G., Aleksieva V. and Mladenov M., (1981): Etiological study of mastitis in 
cows.Vet.Med. Nauki., 18:1. 49-54.

- Tuteja, F.F., Kapur, M.P., Sharma, A., and Vinajaka, A.K., (1993): Studies on bovine subclinical mastitis : Prevalence and microflora. Indian Vet. J. 70, 787-791.

- Van Schaik G., Green L.E., Guzman D., Esparza H. and Tadich N., (2005): Risk factors for bulk milk somatic cell counts and total bacterial counts in smallholder dairy farms in the $10^{\text {th }}$ region of Chile. Prev.Vet.Med. 67:1, 1-17.

- Weidmann, Etchevers, R., Heer G., Rosset A., Gonzalez A., Weidmann R., Monti J., Manfre G., Erni L., and Russi N., (1986): Mastitis incidence on 40selected farms in the department of Las Colonias province of Santo Fe, Argentina. Revista Argentina de production animal, 6:3-4, 215-222.

- Wilson C.D., and Richards M.S., (1980): A survey of mastitis in the British dairy herd. Vet. Rec., 24; 106:21, 431-435.

$$
\text { مدى تو اجد التهاب الضرع الكامن فى قطيع حلاب فى محافظة بنى سويف عرفة مشرف سليمان مشرف و منس هاشم عبد الجواد طلبة }
$$

أجريت هذه الدراسة على 115 بقرة حلابة نم فحصها بواسطة اختبار الكاليفورنيا وذلك لتعيين

مدى نواجد التهاب الضرع الكامن فى قطيع حلاب بمحافظة بنى سويف بالإضافة إلى 28 عينة لبن أخذت من الحليب المجمع فى المزرعة لتعيين عدد الخلايا الجسدية بها. وقد أظهرت النتائج أن متوسط

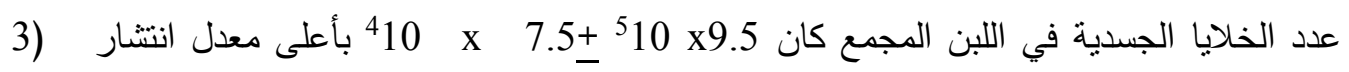

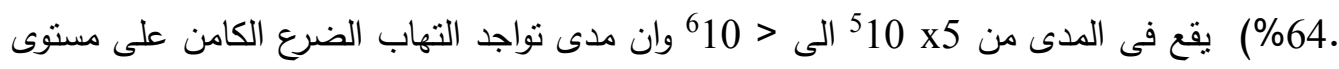


ربع الضرع كان بنسبة 15.2 \% فى حين كانت النسبة 39.1 \% على مسنوى البقرة. وقد أمكن عزل كل من الايشيريشيا كولى (45\%) والمكور السبحى البقرى (21.4\%) والمكور السبحى أجالاكتى (10.8\%) والمكور العنقودى السلبى لاختبار تخثر البلازما (7.7\%) والمكور العنقودى الذهبى (6.2\%) والمكور السبحى الديسجالاكتى (3.1\%) والمكور السبحى فيكاليز (3.1\%) وذلك من ناحية العدوى الفردية بينما أمكن عزل كل من الميكروب السبحى البقرى و المكور العنقودى الذهبى معا بنسبة 6.2\% وكذا المكور السبحى البقرى مع الايشيريشيا كولى بنسبة 3.1\% والمكور السبحى أجالاكتى مع المكور العنقودى الذهبى بنسبة 1.5\% والمكور السبحى البقرى مع المكور العنقوى السلبى لاختبار تخثر البلازما بنسبة 1.4\% وذلك من ناحية العدوى الزوجية. هذا ... وقد نوقتت الأهمية الصحية و الاقتصادية لالتهاب الضرع الكامن. 